\title{
10. Making a debut: myths, memories and mimesis
}

\author{
ANNA COLE
}

The 'first' Aboriginal debutante ball, held in 1968 in Sydney's Town Hall, like a lot of other 'firsts' in history, had a number of historical precedents. Since the early 1960s, smaller-scale local Aboriginal debutante balls had been held in country towns and on Aboriginal reserves around Australia, from Dubbo in New South Wales to Cherbourg in Queensland. ${ }^{1}$ While significant locally and to those who participated these events were largely ignored outside the communities in which they took place. But in 1968, a year after the 'landslide' referendum when 90.77 per cent of Australians voted 'Yes to Aboriginal Rights', a Sydney-based organisation, the Foundation for Aboriginal Affairs (FAA), managed by a young Charles Perkins, held a large-scale Aboriginal debutante ball in the centre of town. ${ }^{2}$

The Foundation which ran the ball was established in 1964 in what Charles Perkins remembered was 'an old funeral parlour believe it or not' on George Street, Sydney, near Central railway station. ${ }^{3}$ With some renovations, the building became known as 'The Centre', a 'solid three storey building in the heart of the city' close to transport links from all parts of the metropolitan area and rural New South Wales. ${ }^{4}$ The organisation focused on civic welfare for the increasing Indigenous population moving into the city at that time. Perkins, while still a young activist and undergraduate was part of the initial fundraising committee and became the first manager of the Foundation immediately after graduation. He remembered the involvement of Candy Williams, Ted Noffs, Col Hardy and Jimmy Little in the early days of the Foundation. ${ }^{5}$ In its fundraising efforts the Foundation drew on the support of various members of

1 Cole 2000: 194-227.

2 See Attwood and Marcus 2007; Cole 2000.

3 Charles Perkins, full interview transcript, <www.australianbiography.gov.au>, p. 5.

4 Report of the First Annual General Meeting of the Foundation for Aboriginal Affairs [hereafter FAA], 12 August 1965, Mitchell Library [hereafter ML], MSS A463/63.

5 Charles Perkins, full interview transcript, <www.australianbiography.gov.au>, p. 5. 
the establishment, including the Lord Mayor of Sydney, who became the first president of the organisation and Professor RW Geddes, senior anthropologist from the University of Sydney, the first chairman. ${ }^{6}$

The Foundation played a recognised role in Sydney's Aboriginal community during the 1960s and early 1970s. It had made a decision at its outset to 'regard as Aborigine any person who identifies as, or is identified by others to be Aboriginal'. ${ }^{7}$ Unlike its government counterparts, such as the Aborigines Welfare Board, the Foundation recognised that its task was to assist in solving the social problems experienced by a group of people, rather than seek to control and define Aboriginal people or engage in precise arguments about the degree of ancestry of particular persons. Of the early days of the Foundation, Perkins remembers:

I used to go and find employment for Aboriginal people around Sydney in the firms, and then I used to meet Aboriginal people coming in from the country, and I used to take them to the hospitals, and I'd ... help them to go out to the prisons ... And we used to run concerts there, oh they used to come in their hundreds from all over the place ... concerts and dances. And they were legendary. ${ }^{8}$

As it got more established the Foundation set up a number of active committees including 'Social Welfare', 'Education', 'Fundraising', 'Health', a 'Women's Auxiliary and a 'Dancing Group'. The dancing committee ran the first Sydneybased National Aborigines Day Observance Committee's Aboriginal debutante ball in July 1966 at the Paddington Town Hall as a fund-raiser. It was this dancing committee that ran the 1968 ball, described by journalist David Jaggar as 'the symbolic coming out of all Aboriginal people, following the referendum of the year before'. ${ }^{9}$

Esther Carroll ran the dance classes leading up to the event. In the crowd on the night were soon-to-be-activists such as Gary Foley dancing alongside the likes of Australian fashion icon Maggie Tabberer. Popular Indigenous musician, Jimmy Little, led the band. The young Indigenous debutantes and their partners were presented to then Prime Minister John Gorton. Photographs and footage of these beautiful young debutantes circulated in national newspapers, on national television via the Australian Broadcasting Commission, and a Japanese film crew filmed the event to show images of the ball back in Japan. ${ }^{10}$

\footnotetext{
6 Report of the First Annual General Meeting of FAA, 12 August 1965, ML MSS A463/63: 3

7 Report of Annual General Meeting of FAA, 12 August 1968, ML MSS A463/63.

Charles Perkins, full interview transcript, <www.australianbiography.gov.au>, p. 5

9 Jaggar, 'Call me old fashioned', HQ magazine, Summer 1992/3: 109-113.

10 Report of Annual General Meeting of FAA, 12 August 1968, ML MSS A463/63; Sydney Morning Herald, 16 July 1968.
} 
Held on an unseasonably warm evening in July, 25 Indigenous women aged between 17 and 21 made their debut in 1968 in front of a 300 plus crowd. Author Ruby Langford-Ginibi who attended the ball with her daughter remembers seeing 'a grey-haired man walk up to her daughter, click his heels in salute, take her hand and lead her to the middle of the dance floor'. ${ }^{11}$ The band struck up and away they waltzed.

I couldn't see very well from my seat so I asked someone, 'who's that man dancing with my Pearlie?' Next day it was all the newspapers. Pearl had made history being the first Aboriginal ever to dance with the Prime Minister. I was so proud. For your daughter to get up there and dance with the man that ran this bloody country was a great high. I just felt real pleased that this had happened to my daughter, in her little handmade dress that I'd got from the Smithos. ${ }^{12}$

On the 40th anniversary of the historic 1968 ball, I was part of an Indigenous and non-Indigenous team who made a short preview for a documentary film about that night. ${ }^{13}$ We wondered what those young women who had debuted in front of the Prime Minister, and the family and friends who had supported them, felt about the ball and the promise of the referendum 40 years on. As we began to talk about the event with former debutantes, their families and friends, it was immediately clear that the night had not become a source of cultural cringe, but triggered memories of good times, of pride and shared joy against a background of much tougher times.

Interviewed on the night by the $\mathrm{ABC}$, Charles Perkins told the reporter, 'the idea behind it is to stimulate a sense of pride and dignity', and to help Aboriginal people 'become part of the community in a way that we think is acceptable'. Just prior to the ball, the Foundation had been fighting a Sydney Council ban on the use of halls for Aboriginal dances in Redfern and Darlington. Perkins, giving evidence at an earlier Parliamentary Inquiry into the Aborigines Welfare Board in 1966, catalogued the mundane and demoralising racial discrimination directed at urban Aborigines:

I would say it [the ban] was based on racial discrimination ... They have never said that to the Greek community or any cultural group ... that has more or less been concerned with incidents near the hall ... a fair judgement has not been made against us ... as far as damage to the hall is concerned one boy playing in the band left his cigarette on the piano and it burned into the piano so we agreed that we would have to pay

11 Langford-Ginibi 1989: 141.

12 Langford-Ginibi 1989: 141.

13 November Films 2008. 
for that and we paid it readily, without any hesitation at all. But there were half a dozen other burns on the piano and we had to pay for those as well. ${ }^{14}$

In this context, the 1968 ball with the Prime Minister attending in the Sydney Town Hall was a coup riding on the optimism of the referendum the year before. In their pretty shoes and carefully applied make-up the young women were not pretending to be white debutantes but self-consciously, proudly, if a little nervously, being Aboriginal debutantes symbolically coming of age as citizens of Australia. In the night, the debutantes interviewed by the $\mathrm{ABC}$ spoke to the camera with a mixture of nervousness and pride. Joyce Davison remembers 'I was eighteen, going on nineteen when I made my debut ... I felt like a princess walking down ... A little black princess' ${ }^{15}$

Joyce, who holds a senior position within the Aboriginal Medical Service in Mt Druitt, was working in a factory in Chippendale in 1968. Her parents had moved from rural New South Wales to the city in the early 1960s in an attempt to avoid having any more of their children removed by the authorities. She explained that two of Joyce's sisters, for example, had been taken one morning from her Aunt's place while their parents attended a family funeral, on the grounds that they had been 'abandoned' Joyce recalled:

I was brought up a sheltered sort of life because Mum had already lost seven of her kids taken away from her first marriage and I think that she was frightened that we would get involved in it ... we might get taken away. You know, don't speak out and say these things, which is, I don't know, right or wrong. ${ }^{16}$

On the night of the ball Joyce 'was a bit disappointed that Mum never came, or Dad. But they had their reasons. They never got into politics or anything but she had that much fear in her, they were frightened that us three youngest kids would be taken'. 'My dress cost six pounds ten', she also recounted with impressive detail. 'I got my beehive hairstyle done at the only Alexandria hairdresser that would serve "blacks"'. ${ }^{17}$ She remembers her boyfriend of the time, now her husband of nearly 40 years, being too shy or ashamed to attend the ball, 'he dropped me off and waited 'round the back of the Town Hall and I went with my cousin's boyfriend of that time'. ${ }^{18}$

Raylene Smith also remembers the 1968 ball vividly and with pride. From the north coast of New South Wales, she was based in Sydney with extended family

14 Perkins 1966 Evidence: 283.

15 Davison 2007.

16 Davison 2007.

17 Davison 2007.

18 Davison 2007. 
in 1968 because of work opportunities in the city: 'Everyone in Sydney was talking about this ball that was coming up, and would I like to be part of that ... To me at the time I was just getting dolled up to go to this big ball'. Raylene and her husband have been married for over 30 years but she told us she has never met her in-laws who 'refuse to socialise with an Aboriginal woman'. ${ }^{19}$

Alice Hinton-Bateup recalled how the ball had made her feel: 'we were part of this big group of Aboriginal people together and it made you feel strong' ${ }^{20} \mathrm{Her}$ father had given the tiara she wore on the night to her and she told us the story of how he got it for her:

I didn't have any money left for the tiara and my Dad had a bet at the races on a Saturday morning and the first bet he had he won the daily double or something like that. And Dad came in with the tiara, just as I was getting my hair done. I mean where did he find the tiara for god's sake! $!^{21}$

Remembering the ball 40 years later, Ruby Langford-Ginibi whose daughter Pearl was chosen by the Prime Minister to dance with remarked:

there were a lot of questions asked about whether Aboriginal girls should be making their debs ball which was, you know, coming out of the white man's culture. It was something to show everybody that we were as good as anybody else and that we could dress up and be nice and pretty too. ${ }^{22}$

She remembered taking apart a dress she bought from a charity shop and sewing it back together to fit her daughter.

Shortly after the ball, Pearl was killed in a hit and run car accident and Ruby, mother of 'the first Aborigine in history to dance with the Prime Minister', remembers the intense financial and emotional difficulty of that time. ${ }^{23}$ Not long after the night of the dance, Pearl's 14-year-old brother was arrested while playing with cricket equipment he had taken with friends from a shed at Newtown High School, and charged with petty theft. It was from the Daruk Training Home, where he was sent for six months for his 'first offence', that he came to his favourite sister's funeral on Christmas Eve, 1968. Langford-Ginibi recalled with pain, how her son, nicknamed Nobby, was kept handcuffed and supervised through the church service:

19 Smith 2007.

20 Hinton-Bateup 2007.

21 Hinton-Bateup 2007.

22 Langford-Ginibi 2007.

23 Langford-Ginibi, pers comm, 2007. 
(Pearlie) had a large funeral ... I buried her with my father because I couldn't afford a plot of my own. Nobby was brought back from the boy's home. A fourteen-year-old boy handcuffed for his sister's funeral. The officer sat with him in the mourning car and later they took him straight back to the home. He wouldn't let anyone mention her name. He locked Pearl away in the back of his mind. ${ }^{24}$

The memories of the former debutantes and their friends and family complicate the image of the success of 'assimilation' or middle class respectability that the ball seemed to confer. While the image of the Aboriginal debutante was being publicised in government media and national papers in the 1960s as 'proof' of the 'success of assimilation', the women involved have memories that disturb this myth. ${ }^{25}$ The pandemic of early deaths among Aboriginal communities, the Stolen Generations, and other stories of every-day racism in country towns around Australia existed simultaneously for the debutantes along with the pictures of white silk and satin dresses, the beehive hairdos and the curtsey to the Prime Minister.

Listening to the women talk, we realised with some enjoyment how little impact the presence of the Prime Minister had on them. In the archival footage of the night, the debutantes appear excited to be 'coming out' to Prime Minister Gorton, but 40 years down the track it was not his presence that had left a lasting impression. More important was the memory of a cousin who had partnered a debutante but since died, or the police presence around the Town Hall on the night, and the difficulty to be had hailing a cab home after the event. If assimilation was failing the Aboriginal women when they debuted in 1968, it was mutual. Attending the ball and curtseying to the Prime Minister was not about assimilation for the women or the organisers. By standing up and being counted as Aboriginal debutantes they gracefully transformed the reality of the genocidal fantasy dressed up as 'assimilation' that wanted to eliminate the category 'Aboriginal' from white Australia.

The national policy of assimilating Indigenous girls through the violence of removal policies and later through the policies of cultural assimilation played a part in the organisers' choice of a debutante ball. The campaign to close down Indigenous community dances in central Sydney and surrounding suburbs also played a part. As with the Freedom Rides led by Perkins a few years before the ball, the event can be seen to make visible longstanding concerns, such as the right of Aboriginal women and men to act in positions of authority, to socialise with whom you chose and perhaps eventually marry, and simply to access and enjoy central town buildings. Significantly, the debutante ball

24 Langford-Ginibi 1989: 141.

25 Cole 2000. 
opened up a public space in the Sydney Town Hall where Indigenous sexual 'coming of age' could be performed. As debutantes, for example, they were not the victim: the statistics of the time that said Indigenous women were twice as likely to be the subject of violent sexual abuse as non-Indigenous. Such a performance could be seen to challenge the intention of the draconian policy and administration of Aboriginal people's personal lives under both 'Protection' and later 'Assimilation' policies that had sought to disperse and eradicate a proud self-identifying Indigenous community. ${ }^{26}$

Reflecting on the ball today upsets the still persistent myth of Indigenous people as the passive victims or on-lookers to modernisation in Australia. As the debutante ball illustrates, Indigenous people were the makers and coproducers of 1960s Australia. The image of the Aboriginal debutante eludes a desire for pure and simple definitions of what it means to be 'Aboriginal in Australia'. This desire to define 'Aboriginal' is challenged by the debutantes who are self-defining, complicated and fully human with all the contradictions that inevitably involves.

At the risk of oversimplifying, I would argue that currently all Indigenous Australians in remote Australia are being stereotyped, largely as degenerate and dangerous, in particular to their own children. This contemporary context contrasts with the words of Ruby Langford-Ginibi who said reflecting on the 1968 ball 'there was hope that we could be presented in a better way ... and that things would get better for our people' ${ }^{27}$ Amidst what Noel Pearson describes as 'a crisis in remote Aboriginal communities which the nation has so far failed to deal with', ${ }^{28}$ it is a historically familiar scenario when the army and government representatives are sent in to Indigenous communities, ostensibly to 'save the children'. ${ }^{29}$ This highly controversial, complex and unresolved territory is part of the wider context in which the debutantes' positive and striking representation of Indigenous women can be placed.

\section{Mimesis}

In engaging in the kind of intersubjective dialogue necessary to make the short preview of the film about the 1968 ball, we were called upon to understand the debutante balls and the women who had participated in them on their own terms rather than as mimicking 'white society' or as an assimilationist success

26 See Read 1982; Goodall 1995: 75-101; Ellinghaus 2003: 183-207.

27 Langford-Ginibi 2007.

28 Pearson 2007.

29 See Haebich 1988; Link-Up (NSW) and Wilson 1997. 
story. During this collaborative project we were influenced by a conceptual framework from postcolonial studies that sees how the 'self' and 'other' are always 'solicited' by each other. ${ }^{30}$ As Vincent Crapanzano wrote in 1985,

One's sense of self is always mediated by the image one has of the other. (I have asked myself at times whether a superficial knowledge of the other, in terms of some stereotype, is not a way of preserving a superficial image of oneself). ${ }^{31}$

This kind of postcolonial approach sees the coloniser/colonised dialectic, for example, as a process that changes the identity of both the colonised and the coloniser. Such ideas work against static notions of identity that say, for example, you can only be a 'real' Aborigine if you conform to a stereotypical set of conditions, such as you come from a remote, traditional community, or can claim urban Indigenous status if you identify as a black activist in a fairly limited stereotypical way. This model of identity denies the realities and complexities of both Indigenous and non-Indigenous lives. In my case, I continue to learn about how my interest in Indigenous cultural politics in the era of the 1960s is revealing of my own identity and personal history along the axis of class, gender and culture.

I presented some of the content of this chapter at the conference in Barcelona from whence this collection originally stems. ${ }^{32}$ At that conference, I talked with my friend Vanessa Castejon about her Spanish family's persecution and exile during the civil war there. This was a conversation we had begun in Geneva some years before when we were volunteering with an NGO providing technical support for the Working Group on Indigenous Peoples at the United Nations. ${ }^{33}$ Vanessa's parent's experiences as exiles from the Spanish civil war, had, she felt influenced her interest and research into Indigenous Australian culture - a daughter of exiles seeking to research and advocate for those exiled within their own country.

At that conference in Barcelona this desire to understand more about the personal stories that motivate our research began to me to feel pressing. Gathering with academics from across Europe and Australia I found myself lost by paragraph two of the carefully argued, bullet-pointed, power-pointed papers wondering, how all of us, some with relatively little lived experience of 'Australia' had

\footnotetext{
Derrida 1981; JanMohamed 1985; Trinh T 1991.

Crapanzano 1985 cited in Trinh T 1991.

Universitat de Barcelona, 28-31 July 2008.

I volunteered with DoCip: Indigenous People's Centre for Documentation, Research and Information in
} 2003. 
become interested in our research topics. If, as postcolonial studies argue, our sense of self is always mediated by our sense of the other what did this interest, especially in Indigenous Australia, say about us?

I had first begun to research Aboriginal debutante balls when writing a $\mathrm{PhD}$ about gender and the cultural politics of assimilation in Australia. ${ }^{34}$ Photos of the Indigenous debutantes smiled graciously out from the social pages of local and national newspapers and the New South Wales state-sponsored magazine Dawn: A Magazine for the Aboriginal People of NSW, published from the late 1950 s to the early 1970s. Indigenous critiques of white feminism had initially led to my interest in what the balls meant to those involved and to the wider politics of assimilation at the time. Indigenous theoreticians and activists challenged the assumptions of white feminists about an easily defined 'shared sisterhood', arguing that Indigenous and non-Indigenous women's interests differed in significant ways. In particular, differences existed around issues of family, sexuality and domestic violence..$^{35}$ For example, when white women called for abortion rights and liberation from being defined only by their maternal role, Indigenous women were fighting enforced sterilisation in some parts of Australia and the violent denigration and refusal of their maternal role through the widespread removal of Indigenous children from their families. When white women fought for the right for sexual freedom, for example, Aboriginal women fought derogatory stereotypes of 'black velvet'.$^{36}$ What might I learn about Aboriginal history and cultural politics if I listened to the women and men involved in these balls instead of reacting from my own feminist prejudices about them?

In the first version of this paper, I had a section a couple of pages long attempting to use the idea of mimesis as explicated by Taussig on colonial exchange to understand the Indigenous debutantes' motivations for being part of the ball. An anonymous reader of the first draft of this essay and Frances Peters-Little my section editor suggested there was less cross-cultural mimetic transformation going on than I might like to think. The ball, as Frances wrote, 'was more a "political strategy" designed by white politicians and black/white political activists' during the 1960s than it was 'a need for individual Aboriginal debutantes and their families to mime whites, for whatever reasons'. The ball in 1968 was a highly political strategised event, but the motivations of the women involved were about the sorts of things they were telling us: a chance to be together as proud young women, a chance to dress up and have some fun.

34 Cole 2000.

35 See Flick 1990: 63; Williams 1987: 66-73; Huggins 1987: 77-83.

36 See Goodall and Huggins 1992: 402. 
Despite my best intentions to learn from what the women involved were saying, I listened but had not really heard them telling me what fun it had been. I puzzled over what I unwittingly thought of as 'western hegemonic' models of femininity, respectability and beauty. I read studies on gender and nationalism that argued, for example, that identities available to women from minority groups are constructed within power relations that provide what they call 'the framework for choice' ${ }^{37}$ In their analysis, identities which seem disempowering in some circumstances may be empowering in others. I thought this made sense for the debutante balls in their historical context.

In Britain, debutante balls were a way of ensuring 'suitable matches' among the elite classes. Traditionally, debutantes came out in front of the Queen, and once 'out' were publicly sanctioned as ready for marriage and procreation. In Australia, a policy of removing Indigenous children, specifically female children, from families and communities could make a public ceremony where Indigenous women publicly announced their 'coming of age' in the presence of their own community and elders a potent ritual of renewal of community and 'right matches' among Indigenous families.

However, as the women kept telling me, they did not see themselves at the time as fighters for equality or civil rights but as women on a big night out. As Christine Anu put it, the women were 'steppin' out in their deadly red shoes. Standin' up cause I'm, wearing something new'.$^{38}$ Within the broader historical context in which I was steeping myself, it was also true that Aboriginal debutante balls were, and are today, quite often 'just social events where girls can be involved outside of sporting events which are still largely dominated by the boys' ${ }^{39}$ The debutantes' real freedom from the historical processes all around them was not to be resisting assimilation or fighting it that night, but just to be themselves young, stylish, 'groovy' women having fun.

The taxis that would not stop for them at the end of the night because they were 'Aboriginal', which some of the debutantes remembered 40 years on, or the police presence outside because of a large gathering of 'Aboriginals' in central Sydney, are another part of the same story. But having a ball, neither fighting nor 'resisting' but being proud of whom you are, dancing and enjoying a night out, was the greatest freedom of all in that moment. As the former debutantes told me it was about being with a big group of people, dressing up, looking great, feeling proud, knowing about the taxis and the police presence but knowing that we are more than the sum of our oppressions.

37 See Yuval-Davis and Anthias 1989: i-iv

38 Anu 1995: track 10.

39 Frances Peters-Little, editorial comments, 2009. 
I think my over-working the concept of mimesis was, in part, a bit to do with looking too long and too hard at one thing - an occupational hazard of the academic researcher. Your subject starts to swim in front of your eyes. However, as I thought more about this chapter, it dawned on me that the process of mimesis was mine. The 'mimetic faculty' as Taussig defines it is 'the faculty to copy, imitate, make models, explore difference, yield into and become other' ${ }^{40}$ He notes that 'writing itself is a mimetic exchange with the world ... it involves the relatively unexplored but everyday capacity to imagine, if not become the other'. In an 'older language', writes Taussig, this is 'sympathetic magic' and is as necessary to the very process of knowing as it is to 'the construction and subsequent naturalisation of identities'.$^{41}$

Mimesis plays this trick of dancing between the same and the very different. An impossible but necessary, indeed an everyday affair. Mimesis registers both sameness and difference, of being like and being other. Creating stability from this instability is no small task, yet all identity formation is engaged in this habitually bracing activity. ${ }^{42}$

If mimesis is the process of copying or imitating something in order to change yourself as well as the thing you imitate, isn't that what all of us who write about Aboriginal History are doing, at least in part? As well as helping me decipher more about the academic culture of which I am part, I felt I knew something more about this process of mimesis from my personal history. My mother's movement from working-class Londoner, with the 'wrong' South London accent that she modified to more ' $\mathrm{BBC}^{\prime}$ English and later to professional middle class British-Australian was, in part, a process of imitation and assimilation. I knew something about the processes of assimilation from my own life as a British immigrant to Australia. The hiding involved, the invisible differences, and the re-invention as well as the freedom to be, to some extent, who you want to be. To identify with whom you choose from a range of new possibilities. To wear the finest clothes you save for one day, for example, and the bargain clothes from the Good Samaritans another.

It is about ten years ago that I attended my first Indigenous debutante ball, at Sydney's La Perouse with my friend Maria Nugent, and began listening and talking to those involved in the balls and thinking about the questions they raise about feminism, assimilation, identity and later, mimesis. It occurs to me now as I write this that I often feel like I am making my debut. As a 'new Australian' emigrating with my family from England to Western Australia, age seven. Being told to 'bring a plate' to my first Australian school sports carnival 
and turning up with just that - an empty plate, feeling like an idiot as I did many times navigating the unchartered colloquialisms and invisible differences of the 'new Australian'. I married a man from London and live back here now, making my debut again, navigating a new world of English universities and now, as my kids get older, schools. I am a historian working in an Anthropology department. An Australian in London, a bit of a pom in Australia. A mother with young kids stumbling between motherhood and research. As I learn about how to keep a rhythm between my various roles alive, my desire to listen and learn, to share with and understand others who have juggled the demands of many roles and identities, takes on a new urgency and meaning. 'A fragmented identity is a strange thing' writes John Docker,

[y]ou always feel other people are more secure and assured in their identity, which they're most certainly not. And you always have a feeling of not fully knowing yourself, or why strange desires, passions, and identifications erupt and endure. ${ }^{43}$

\section{Acknowledgements}

Many thanks to Lara Cole, Rani Chaleyer, Anne Delaney, Janine Matthews, and the former debutantes and their family who appear in the documentary preview: Joyce Davison, Ruby Langford-Ginibi, Rayleen Clarke and Alice Hinton-Bateup. Thanks also to Carole Cole and Frances Peters-Little for comments on the draft, and to Ann Curthoys, John Docker, Vanessa Castejon, Peter Read, Terri-Ann White, and Sue Ballyn for the Barcelona conference. Some material in this paper was first published in Studies in Australasian Cinema (2008, vol 2(1): 5-13).

\section{References}

\section{Primary sources}

Report of the First Annual General Meeting of the Foundation for Aboriginal Affairs [hereafter FAA], 12 August 1965, MSS A463/63, Mitchell Library, Sydney.

Report of Annual General Meeting of Foundation for Aboriginal Affairs [hereafter FAA], 12 August 1968, MSS A463/63, Mitchell Library, Sydney.

\section{Secondary sources}

Anu, Christine 1995, Stylin' Up, Mushroom Records.

43 Docker 2001: ix. 
Attwood, Bain and Andrew Markus 2007, The 1967 Referendum: Race, Power and the Australian Constitution, Aboriginal Studies Press, Canberra.

Cole, Anna 2000, 'The Glorified Flower. Race, Gender and Assimilation in Australia', unpublished PhD thesis, University of Technology, Sydney.

Crapanzano, Vincent 1985, 'A reporter at large', New Yorker, 18 March 1985: $8-10$.

Davison, Joyce 2007, Interview in Dancing with the Prime Minister, Lara Cole (dir), November Films.

Derrida, Jacques 1981, Dissemination, B Johnson (trans), University of Chicago Press, Chicago.

Docker, John 2001, 1492. The Poetics of Diaspora, Continuum, London and New York.

Ellinghaus, Katherine 2003, 'Absorbing the "Aboriginal Problem": controlling interracial marriage in Australia in the late 19th and early 20th centuries', Aboriginal History 27: 183-207.

Flick, Barbara 1990, 'Colonization and decolonization: an Aboriginal experience', in Playing the State: Australian Feminist Interventions, Sophie Watson (ed), Verso, London and New York: 63-67.

Goodall, Heather 1995, "Assimilation begins in the Home". The state and Aboriginal women's work as mothers in New South Wales, 1900 to 1960s', in Labour History: Aboriginal Workers, Ann McGrath and Kay Saunders (eds), Australian Society for Study of Labour History, Sydney: 75-101.

- and J Huggins 1992, 'Aboriginal women are everywhere. Contemporary struggles', in Gender Relations in Australia: Domination and Negotiation, $\mathrm{K}$ Saunders and R Evans (eds), University of Queensland Press, Queensland: 398-424.

Haebich, Anna 1988, For Their Own Good: Aborigines and Government in the Southwest of Western Australia, 1900-1940, University of Western Australia Press, Perth.

Huggins, Jackie 1987, 'Black women and women's liberation', Hecate 13(1): 77-83.

JanMohamed, Abdul 1985, 'The Economy of Manichean Allegory: the function of racial difference in colonialist literature', Critical Inquiry 12(1): 59-87. 
Passionate Histories

Langford-Ginibi, Ruby 1989, Don't Take your Love to Town, Penguin Books, Australia.

— 2007, Interview in Dancing with the Prime Minister, Lara Cole (dir), November Films.

Link-Up (NSW) and Tikka Wilson 1997, In the Best Interest of the Child? Stolen Children: Aboriginal Pain/White Shame, Aboriginal History Monograph 4, Link-Up NSW Aboriginal Corporation and Aboriginal History Inc, Canberra.

November Films 2008, Dancing with the Prime Minister, Lara Cole (dir), DVD.

Pearson, Noel 2007, 'No more victims', The New Statesman, 16 August 2007, accessed 10 May 2008: <www.thenewstatesman.com/200708160023>

Perkins, Charles 1966, Part 1, 'Report and Minutes of Proceedings', in Report from the Joint Committee of the Legislative Council and Legislative Assembly upon Aborigines Welfare, Parliamentary Papers, 2 June 1966: 283.

Read, Peter 1982, 'A double-headed coin: protection and assimilation in Yass, 1900-1960', in All that Dirt. Aborigines 1938, History Project Inc, Canberra.

Smith, Raylene 2007, Interview in Dancing with the Prime Minister, (preview), November Films.

Taussig, Michael 1993, Mimesis and Alterity: A Particular History of the Senses, Routledge, London and New York.

Trinh T, Minh-ha 1991, When the Moon Waxes Red: Representation, Gender and Cultural Politics, Routledge, New York and London.

Williams, Elaine 1987, 'Aboriginal first, women second', in Different Lives: Reflections on the Women's movement and Visions of the Future, Jocelyn Scutt (ed), Penguin, Ringwood: 66-73.

Yuval-Davis, Nira and Floya Anthias (eds) 1989, Woman-Nation-State, Palgrave Macmillan, London. 